\title{
La imagen fija como área de investigación estética
}

\author{
Gonzalo Leiva Quijada \\ Instituto de Estética, Facultad de Filosofía, Pontificia Universidad Católica de Chile. \\ gleivaq@gmail.com
}

\section{Introducción}

La revista Aisthesis es una referencia cultural chilena que por más de cincuenta años, y a partir de las iniciales disciplinas artísticas, ha aportado y ampliado el horizonte analítico a nuevos objetos de estudios. De hecho, la investigación formulada en el proyecto FONDECYT $\mathrm{N}^{\circ} 1110385$ sobre "Representaciones fotográficas e Imaginarios visuales" constató que estos constructos tienen en la prensa y las revistas de corriente principal -como es el caso de Aisthesis- dos instancias ejecutivas de socialización y recepción de dichos imaginarios, tanto en la cultura popular como en la cultura universitaria.

Mis contactos con la revista Aisthesis son tempranos; se remontan a las búsquedas pre-Internet de los años ochenta, cuando fueron publicados los números en los que nuestros maestros del Instituto de Estética escribieron y asentaron textos fundacionales sobre poesía, teatro, cine, artes plásticas y cultura tradicional.

Tiempo después, en el año 2002, por deseo explícito del director del Instituto en aquella época, el profesor Jorge Montoya, me hice cargo del número 35 de la revista, el cual se consagró a la fotografía en Latinoamérica. Este, además de ser un número sui generis, pues contamos con el diseño del destacado creador Antonio Larrea y la participación ampliada de numerosos articulistas y fotógrafos, se convirtió en un volumen de referencia y el primero, en el contexto nacional y latinoamericano, en estar dedicado a las relaciones estéticas y los contornos del médium fotográfico. Este impulso se vio aparejado por las jornadas sobre patrimonios visuales, dictadas en el Centro de Extensión, y por la configuración del sistema de Educación Continua 
que estableció, a partir de la imagen -en particular de la fotográfica-, un universo representacional que requería de reflexión estética. De un modo direccional, los ejercicios escriturales se desarrollaron en contigüidad con la creación de los diplomados "Fotografía, Patrimonio e Identidad", "Comunicación Visual" y "Fotografía Digital”, que por más de diez años generaron múltiples polémicas, reflexiones, preocupaciones y teorizaciones.

\section{La territorialidad de la imagen}

La imagen es un campo de investigaciones en la cultura actual. Cuando concordamos con las imágenes, nos encontramos ante una problemática cuyas territorialidades no podemos trazar con exactitud. Bien se plantea con la fórmula que cada imagen es el resultado de movimientos de sedimentación y cristalización; estos movimientos poseen trayectorias históricas, antropológicas, psicológicas, etc., de tal modo que nos llevan a pensar la imagen como un momento energético o dinámico, sin importar cuán específica sea su estructura (Didi-Huberman).

En efecto, los desplazamientos de la imagen nos han indicado la aparición de un giro icónico, el cual, justamente, ha tensado las posibilidades metodológicas frente a los artefactos visuales, reconociendo la complejidad de exigencias ontológicas que conlleva este tema. Hoy más bien hablamos de estudios visuales donde transitan las imágenes. Este giro icónico da importancia tanto a las propiedades físicas de las imágenes como a sus funciones sociales y modos de almacenamiento, exhibición y conservación. Así, surge un amplio campo semántico que adscribimos a las imágenes; por ejemplo, palabras como representación, presentación, aura, mostración, situacionalidad, recontextualización, deconstrucción, etc., constituyen contenidos y paradigmas disciplinarios que ayudan a comprender los efectos de realidad de dichas imágenes.

En diferentes universos representacionales y desde múltiples enfoques -la historia del arte, la iconografía, la cultura visual, los estudios culturales, la antropología visual y la memoria visual, entre otros-, se ahonda, a partir de las imágenes fijas, en esta insaciable búsqueda de significados adscritos en contextos específicos. Como lo planteamos originalmente, las imágenes hoy por hoy constituyen momentos fenomenológicos, hermenéuticos y, desde hace muy poco, también neurológicos y cognitivos. Con esta variedad de enfoques, las imágenes fijas han pasado a ser evidencias de los paradigmas culturales desde el siglo XVIII, con la modernidad, y hasta el siglo xx, con la postmodernidad. En efecto, las grandes narrativas metadiscursivas han intentado ejemplificar los alcances transhistóricos de sus propuestas imaginarias. Hoy, las industrias del entretenimiento, la política, la publicidad y los circuitos comerciales del arte y del consumo, saben que la imagen fija es un dispositivo estético con gran poder de influencias, acciones y acceso a audiencias. En la realidad chilena y latinoamericana, las disputas desde las imágenes han sido armas sociales de conciencia democrática 
y/o resultado de las ordenaciones de las artes industriales que han nutrido un extenso esfuerzo de significación cultural en nuestro continente.

\section{La memoria de las imágenes en América Latina}

El teórico Roland Barthes indica que las imágenes -en particular la fotografía-, como parte de la modernidad, en esencia no podrían constituir memoria, sino que se transforman en "contramemoria", dado que el pasado es inmutable. Nosotros hemos hurgado en los resabios culturales que han sido plasmados por investigaciones apuntando a constituir imaginarios desde la memoria visual. En efecto, la memoria de la imagen se nutre de la evanescencia de ella, de su muerte oscurecida por el beneplácito de la vida y, en particular, por el arribo de nuevas imágenes que se ajustan al tiempo histórico.

El panorama de las imágenes fijas presenta puntos neurálgicos: dispersión, pérdida, constitución de tradiciones recientes, olvidos de las imágenes precolombinas. América Latina constituye un medio de tradiciones recientes, de búsquedas propias, las cuales han adquirido mayor fuerza en el siglo Xxi, gracias a las nuevas tecnologías que son utilizadas por pléyades de creadores para constituir espacios de identidad y cooperativismo. De hecho, la memoria de las imágenes se va desplazando en los medios sociales de comunicación y, particularmente, en las redes de Internet, donde su persistencia no pasa de algunos segundos. Por esto, la imagen se nutre de nuevos dispositivos de instantaneidad, originalidad, hibridismos, saturación de color, etc.; es decir, un cúmulo neobarroco propio de la cultura popular latinoamericana, que circula por los medios tecnológicos, abriendo sendas de indagación sobre las preocupaciones de lo que somos como identidad tensada entre lo propio, lo de moda, la mundialización y el mercado.

Los múltiples corpus que construyen la memoria, muchos felizmente resguardados en colecciones privadas, gabinetes, museos, centros culturales y comunitarios, se constituyen como delicadas metáforas contra el olvido y la ansiedad. De este modo, la memoria de las imágenes y los archivos se asienta en imaginarios dinámicos y activantes de la consciencia ciudadana y sus sentidos identitarios.

\section{Los nuevos territorios por conquistar, desde el análisis de las imágenes fijas}

A nuestro entender, existen tres unidades de contenidos donde la mirada reflexiva sobre las imágenes no se ha situado con fuerza en nuestro país: el cuerpo, el paisaje y las imágenes de la esfera pública.

En esta línea analítica, consideraremos las apariciones de la corporalidad y sus acciones como matrices estéticas que establecen redes en una relación de intercambio, 
de poder y de saberes. Las imágenes del cuerpo largamente guardadas en espacios privados visibilizan los intercambios entre el cuerpo individual y el social que no responden a las lógicas dominantes. Por lo mismo, se hace necesario configurar a este heterogéneo y disperso archivo. Las experiencias de las imágenes fijas por la corporalidad en su tránsito histórico conforman tramas representacionales específicas que apuntan a la presencia de una semiótica de la huella, así como a una encarnación simbólica y a la conformación de particulares memorias corporales.

Vislumbramos la importancia de las imágenes corporales en la medida en que toda interacción social es inicialmente corporal y se ordena de acuerdo con una serie de convenciones y rituales, conformando así el ser invisible de lo socializado. Desde una perspectiva sudamericana, estos cuerpos se constituyen en productores de significantes culturales en la vida comunitaria. Por su parte, entenderemos las imágenes de la corporalidad, en un sentido extendido, como fuerzas expresivas, teniendo en consideración actos, comportamientos, actitudes y prácticas corporales que unen la reflexión estética, la política y la ética desde la corporalidad (Taylor y Fuentes).

Respecto del paisaje, se debe traspasar la versión categorizada por la pintura y la fotografía de género del "paisaje natural", para adentrarse en el reconocimiento poético y topográfico. Es este principio de construcción del "punto de vista" lo que finalmente constituye el paisaje. El paisaje no existe sin imagen de él. Tenemos una labor investigativa que tejer tanto en relación con la heterogeneidad y desmesura del paisaje, como con la aplicación de nuevas epistemologías para su comprensión en el espacio del Cono Sur.

Las ciudades, en particular, constituyen en sí mismas una problemática propiamente latinoamericana del nuevo paisaje en su desmesura, en las marginalidades que lo constituyen y las subculturas que ahí se gestan. Al respecto, el ejercicio estético de la contemplación y la acción reflexiva de las imágenes construidas es el primer paso para ir desplegando las virtudes territoriales de estos paisajes. Además, se hace importante realizar una nueva metodología revisitando las geografías para ver sus diálogos locales y regionales. Estos territorios deben universalizar sus elementos naturales, junto con connotar el marcado fluir de su patrimonio como parte constituyente del nuevo concepto de paisaje que debemos configurar.

Se hace también pertinente analizar las imágenes en la esfera pública y, en particular, en los ámbitos ciudadanos. Pero no me refiero a la fotografía de prensa o al documental, sino a las imágenes no oficiales. Dentro de esta perspectiva, cabe revisar, analizar y sistematizar variadas iconografías, las cuales se deben considerar dentro de una geopolítica de nuevas miradas. Las iconografías son hoy efímeras, por lo mismo, debe haber un afán de registro, en particular en aquellas problemáticas que se transforman en manifestación pública dentro de escenarios específicos, como el político y el de los derechos civiles. Todos estos ejercicios ciudadanos de multitudes anónimas y movimientos sociales que exigen justicia, derechos y libertades han hecho que la calle sea nuevamente el gran escenario público, como lo había sido ya en la 
década de los años sesenta. Una áspera disputa se instaura en la recepción de estas nuevas imágenes de América Latina, en la medida en que estas "marcas crónicas" visibilizadas en corpus diversos han sido escasamente consideradas y resguardadas.

Sin duda, la aparición de los subalternos en la representación oficial latinoamericana como demandantes de cambios políticos marca uno de los lineamientos analíticos centrales. En este contexto, las iconografías surgen, dialogan, constituyen panfletos, afiches, esténciles, pancartas, declaraciones, editoriales u otros medios expresivos y visuales.

Nuestra propuesta es que las imágenes fijas hoy se articulan epistemológicamente desde una doble trama: por un lado, la "corriente dramatúrgica", en la que los grupos sociales escenifican sus problemáticas a través de imágenes; por otro lado, la "corriente reivindicativa", ejercicio de los colectivos sociales que se toman la calle para las trasgresiones, la escenificación de la protesta política o la respuesta crítica como hechos efímeros que deben ser registrados.

\section{La imagen fija como catalizador cultural}

Como he bosquejado, estas tres unidades de referencialidad de imágenes fijas -el cuerpo, el paisaje y la esfera pública- merecen un replanteamiento estético. No solo se deben constituir entramados epistemológicos para su registro, análisis y comprensión; además, se hace necesario, desde los andamios heterogéneos de los corpus visuales, construir una articulación comprensiva en su permeabilidad simbólica con sus contextos, su situacionalidad y sus narrativas. Claro está que las reconsideraciones sobre las imágenes fijas se han nutrido de nuevas variantes analíticas que rompen el tradicional encasillamiento entre alta cultura y cultura popular, pues en estos testimonios visuales trasunta una identidad latinoamérica particular, donde la contingencia y tensión socio-política de cada país fue definiendo configuraciones culturales específicas.

La centralidad y la urgencia de estas tareas de investigación obedecen a la premura por acortar espacios y lograr afianzar las redes entre los centros de investigación, las universidades y los diversos núcleos de trabajo sobre estas temáticas. Sin duda, la revista Aisthesis, en este contexto, es y será una gran aliada para formular preocupaciones estéticas unificadoras. Pues ya sabemos que desde el giro icónico, las imágenes fijas se han transformado en catalizadoras de los emergentes imaginarios culturales. No dudamos que estos planteamientos sobre la imagen fija serán retomados en los números futuros de la revista Aisthesis en su tarea enunciadora de aperturas editoriales y epistemológicas atentas al pulso del tiempo. 